\title{
The Land Suitability Evaluation for Samut Prakan Province in Thailand for Eco Industry Development by Applying the Geographic Information System
}

\author{
Suphattra Ketsarapong ${ }^{1}$, Prapapan Ketsarapong, ${ }^{2, *}$ \\ ${ }^{1}$ Department of Mechanical System and Innovative Industrial Engineering, School of Engineering, Sripatum University, Thailand \\ ${ }^{2}$ Department of Industrial Engineering, Faculty of Engineering at Sriracha, Kasetsart University Sriracha Campus, Thailand
}

Copyright $(02016$ by authors, all rights reserved. Authors agree that this article remains permanently open access under the terms of the Creative Commons Attribution License 4.0 International License.

\begin{abstract}
The purpose of this study is to present the Geographic Information System (GIS) that supports land suitability evaluation for the development of target land in Bang Pu Sub-District Municipality in Samut Prakan Province in Thailand in order to promote the concept of the eco-industrial town. GIS was applied as the research methodology. SIEVE analysis was employed to evaluate suitable land. There are four factors involved in evaluating the land in this study. The first factor is the industrial density factor. The second factor is the industrial cluster factor. The third factor is the accessibility to green and recreation areas factor. The last factor is the risk to the urban ecology and environment factor. Each factor has three score levels in descending order: 3,2 , and 1 . It was found that suitable target land could be found in five locations. There were 408 industrial factories on the target land (68.92\% of 592 Group 3 factories). The findings are important information for the Samut Prakan Provincial Office to select suitable land, to make strategic and master plans, and to manage resources in order to maximize efficiency and develop the province into a model eco-industrial town in accordance with the province's vision.
\end{abstract}

Keywords Eco-industrial Town, Land Suitability, Geographic Information System, Thailand

\section{Introduction}

In the past, business conduct in most of the factories focused on managing and improving business processes in order to react to global trade rules and regulations, but ignored the other important conditions that would enhance business sustainability [1]. For example, the impacts of the pollution released into the environment that affected the quality of life of the people living in the area were largely ignored [2]. Factories are still not aware of zero waste production when raw materials are converted into goods [3]. Therefore, there are many problems such as the lack of natural resources (water, energy, fuel, etc.), the reduction of forest, which destroys the ecology and biology, and global climate change, which impacts the whole world $[3,4,5,6]$. Many researches around the world have introduced concepts of industrial ecology for sustainable development $[5,7,8,9$, $10,11,12,13,14,15]$. The area development into an eco-industrial town is one of the solutions that will lead to sustainable growth of business, industry, environment and society $[16,17,18]$. An eco-industrial town is development that focuses on economic ideas that seek to enhance profit, and ecological ideas that focus on balancing industry, community and environment. An eco-industry is a group of businesses that manage resources effectively together, which leads to a balance in the economic, environmental and social aspects of the community [15]. It focuses on a development strategy that co-exists with the environment, and this will lead to sustainable development $[16,18]$. The development of an eco-industrial town initially starts with the development of the 'green factory' to reduce and prevent external impacts $[6,15]$. For example, each factory is located in the same general location and improves the production line and develops the products to reduce the pollution that impacts the environment, as set by legal and environmental standards that have to be followed by applying clean production, green productivity, and eco-efficiency. When a factory becomes a green factory and continues to develop to win the support from industrial groups, it is possible to become an eco-industrial park or EIP $[18,19]$. For example, a green factory located in the same industrial group attempts to create a network to exchange production waste; uses an environmental management system, such as a wastewater treatment system, and has a friendly environmental production chain management system, the area can then be regarded as an eco-industrial town. This area will include and connect the industrial area and a group of factories, local stakeholders and surrounding communities and develop 
other things along with the industry. It can then be "a nice place to live with industry" [20]. As a result, the development to an eco-industrial town is very necessary to build the integration at the factory group level to create a network of eco industries that has land suitability and no ecological disasters. The area that is ready with the basic infrastructure and traffic network is a city that supports the people living in the community. For all those reasons, development into an eco-industrial town requires the analysis the land suitability to assure that the area is suitable to be developed into an eco-industrial town [21].

This research article is purposed to present Land Suitability Evaluation for the development into an eco-industrial town in the target area in the municipal of Bang Pu located in Samut Prakan province, Thailand using the Geographic Information System,; GIS, which is a spatial data management system. It is useful for the Land Suitability Evaluation, which is a tool used extensively by the SIEVE Analysis technique which converts the factor data into a geographic map and then all of the maps are overlaid according to Boolean algebra. The areas with higher scores will be overlaid on a geographic map. The result of the analysis is shown on a geographic map. This research article is divided into 5 parts: the introduction, the study Area, the methodology, the results of the research and the conclusion.

\section{Study Area}

The study area was determined by Samut Prakan Industry Office and other related offices of the province called the steering committee, which works on the development of Samut Prakan as an eco-industrial town by selecting a study area in the municipality of Bang $\mathrm{Pu}$, Samut Prakan province as shown in Figure 1.

This area is quite important for the economics of this province. The area covers around 63.50 square kilometers. Its shape is rectangular and is along the east coast. Sukhumvit Road and irrigation canal are in the middle of the land starting from 29.250 kilometers on Sukhumvit Road to 51.150 kilometers. This area covers four Tambons including Thai Ban, Thai Ban Mai, Bang Pu and Bang Pu Mai. The population is 118,670 with 49,167 houses and 592 type 3 industrial factories. This area has factories and communities close to each other, which causes environmental problems quite often. The land development is pretty effective because it conforms to the 4-year development plan of Samut Prakan, (2015-2018) and the development plan of the municipality of Bang Pu (2014-2016). It also connects with the strategic planning of the development group of the provinces in central Thailand (Chachoengsao, Prachinburi, Nakhonnayok, Srakaew and Samut Prakan province). Therefore, this is an important reason why the municipal of Bang Pu was selected to be the study area for the eco-industrial town.

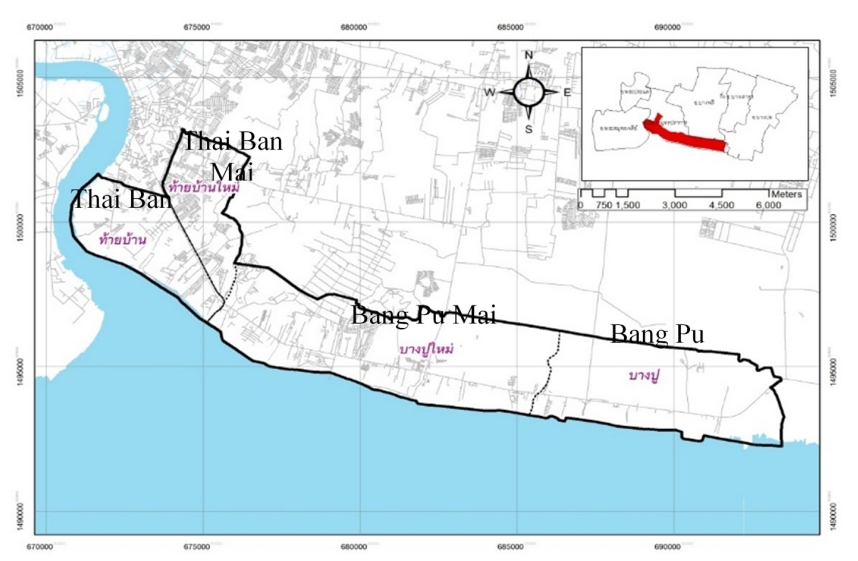

Figure 1. A geographic map of the study area

\section{Methodology}

To define the purposes, this research article was conducted with the research framework shown in Figure 2. There are four steps as follows: 


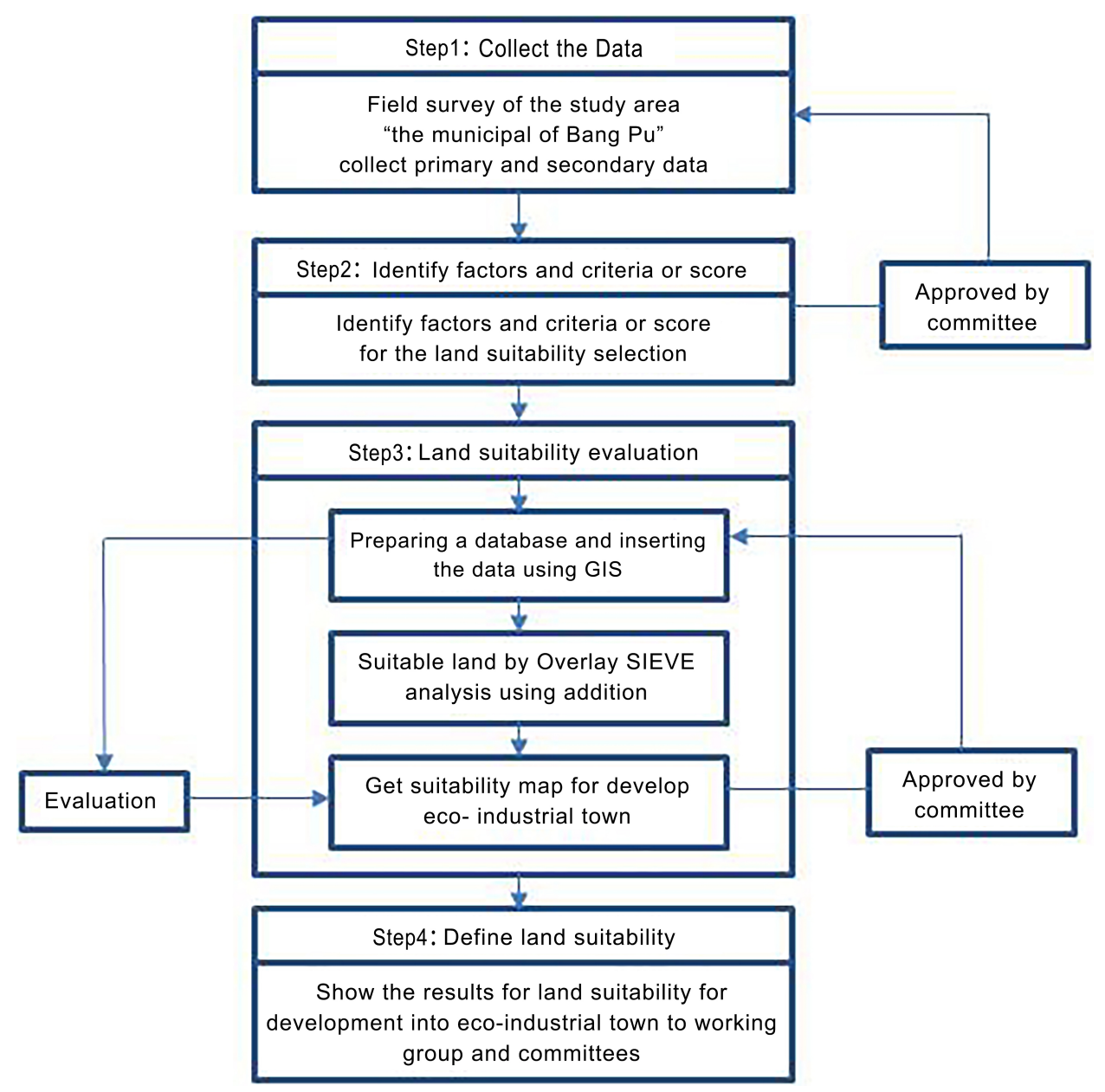

Figure 2. The step of research methodology

\subsection{Step 1 Collect the Data}

This step starts with a field survey of the study area, the municipality of Bang Pu. The location is saved as the Global Positioning System (GPS) result for the factories in the study area. The primary data are collected by interviewing several stakeholders such as governors, factories and communities. Furthermore, secondary data are also collected, such as building use, which are then divided into industrial buildings, residential buildings, recreational buildings (with data from the Department of Public Works and Town \& Country Planning) and other information needed for GIS, such as information categorized by type of industry from the International Standard Industrial Classification of All Economic Activities or ISIC. In 1986, there were factories that received complaints about environmental problems which led to the Public Health Act in 1992 and the Hazardous Act in 1992. Information was also provided from Google Maps. As a result, this study determined 3 factors, which are the industrial density factor, the industrial cluster factor, and the accessibility to green and recreation areas factor. After review with the steeling committee, it was suggested to have an additional factor at the community hearing on the risk to the environment. This urban ecology and environment risk became the fourth risk factor.
Therefore, all of the information mentioned above is analyzed to identify the factors, criteria and score and land suitability is then evaluated by GIS in steps 2 and 3, respectively.

\subsection{Step 2 Identify Factors and Criteria or Score}

This step is divided into two sub-steps: the first sub-step is to identify the factors which indicate the suitability of the area for development into an eco-industrial town. The factors are considered based on the data from step 1. A field survey of the physical, economic and social aspects is also conducted. Primary data are collected from interviews, and the secondary data are collected from several stakeholders. Related research articles are also reviewed. There were four main factors identified from the data: the industrial density factor, the industrial cluster factor, the accessibility to green and recreation area factor and the risk to urban ecology and environment factor. The second sub-step determines the criteria or score for each factor. The concept of factors and criteria or score identification are as follows:

\subsubsection{Industrial Density Factor}

Industrial factory integration will lead to convenient and energy safe ways of network building, or information 
exchange [4]. Moreover, this will lead to the procedure of technology exchange or resource sharing, such as a wastewater treatment system, and a trash management system, which will affect the success of the development of an eco-industrial town in the future. Therefore, an area that has industrial factory integration will be an area that is suitable for the development of an eco-industrial town. In this research article, the industrial density factor is identified based on building use, and the industry type is based on the classification by the Department of Public Works and Town $\&$ Country Planning. The score is determined by using the distance from factory to factory. The concept of traveling that saves energy the most is walking. According to the standards of the town planning of the Department of Public Works and Town \& Country Planning, the average walking distance of Thai people is $500-800$ meters subject to the environment of the area. In this research article, there is a radius connection and score, which is divided into 3 levels: 3 (0-500 meters), 2 (501-1,000 meters) and 1 (over 1,001 meters) as shown in Figure 3.

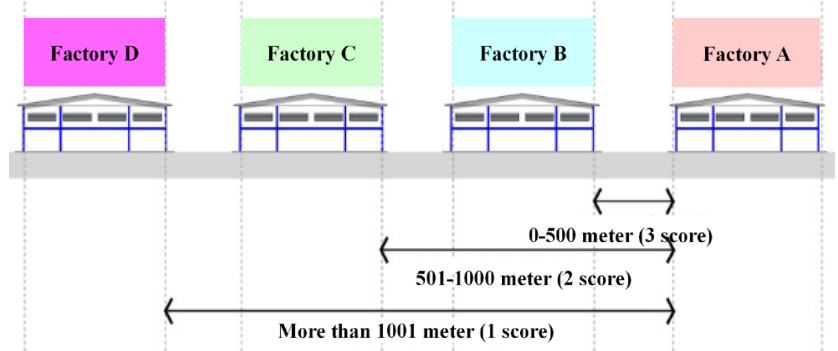

Figure 3. The concept to determine the industrial density factor and score

\subsubsection{Industrial Cluster Factor}

An industrial cluster is a group of businesses and related stakeholders that conduct their business in the nearby area (geographical proximity). They help, connect and support each other (commonality and complementary) in various ways such as services, commerce associations, seminar or development research to upgrade the capability of the competition by increasing productivity and creating innovations together. As a result, a group of the same type of industrial businesses will support the businesses and move the target area forward as an eco-industrial town. In this research article, the industrial group factor allocation is based on the information categorized by the type of the industry by the International Standard Industrial Classification of All Economic Activities or ISIC, which divides the industries into 9 clusters including the food industry, the textile Industry, the wood Industry, the paper industry, the chemical product industry, the non-metallic mineral industry, the basic non-metallic mineral industry, the machine metallic industry and other production industries. The score is determined by using the distance from factory to factory the same type. The industries of the same type that are in walking distance will be more suitable for industrial cluster development and the average walking distance of Thai people is around 500-800 meters, subject to the environment of the area. In this research article, the radius connection and score are divided into 3 levels: 3 (0-500 meters), 2 (501-1,000 meters) and 1 (over 1,001 meters) as shown in Figure 4

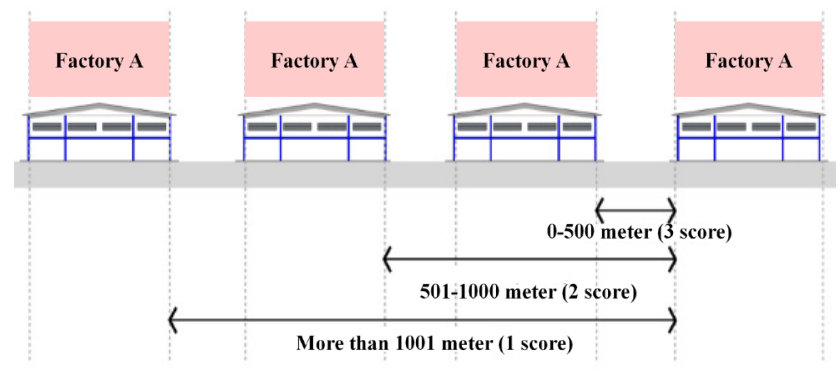

Figure 4. The concept to determine the industrial cluster factor and score

\subsubsection{Accessibility to Green and Recreation Area Factor}

A green or park zone can be developed to be a green buffer zone which can be used as the lung of industrial factories. It will help absorb pollution and dust that remains in the industrial zone. For the public, the benefits of a green zone can be as a recreation area of the community, and an indicator of the quality of life of those who live in the city $[19,22]$. So if there is any area located in the service of the green or park zone, which means it tends to be developed as Green Buffer Zone and promote it to be an Eco-industrial town. In this research article, the factor of green and recreation area is based on the information about building use, the recreation type as classified by the Department of Public Works and Town \& Country Planning, along with the field survey of the study area. The score is determined by using the distance to green and recreation areas in the city. The concept of traveling that saves energy the most is walking. According to the standards of the town planning of the Department of Public Works and Town \& Country Planning, the average walking distance of Thai people is $500-800 \mathrm{~m}$. subject to the environment of the area. In this research article, the Radius Connection and score is divided into 3 levels: 3 (0-500 meters), 2 (501-1,000 meters) and 1 (over 1,001 meters) as shown in Figure 5.

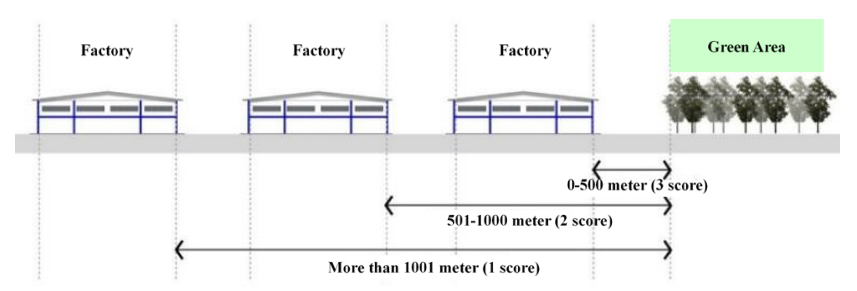

Figure 5. The concept to determine the accessibility to green and recreation area factor and score

\subsubsection{Risk to Urban Ecology and Environment Factor}

Factories affect the surrounding area and ecology. They should be observed carefully. Therefore, if anyone located 
within the boundary line is affected by the factories and complains, that means there is a risk to the urban ecology and environment factor in that area. There should be a solution to reduce the effects of factories on people living in the area. In this research article, the factors of the risk to the urban ecology and environment are based the distance of the factories that receive complaints about the environment from the community. The score level is considered by the buffer zone which is divided into 3 levels; 3 (0-50 meter), 2 (51-150 meter) and 1 (151-500 meter.) as shown in Figure 6. This refers to the report of the problems about the distance between the industry and the community in the Map Ta Phut Estate, Rayong province since this is a similar type of industry to the study area.

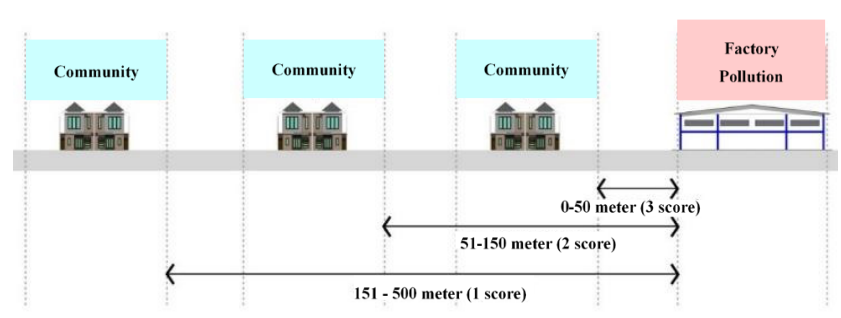

Figure 6. The concept to determine the risk to the urban ecology and environment factor and score
After determining the factor and the score for the land suitability evaluation, there was a meeting with the working group for provincial development into an eco-industrial town. They finally identified 4 main factors: the industrial density factor, the industrial cluster factor (which was divided into 9 minor factors for each type of industry), the accessibility to green and recreation area factor and the risk to the urban ecology and environment factor. In total there are 12 factors in this research article. The factors and score are shown in Table 1.

\subsection{Step 3 Land Suitability Evaluation}

ArcView GIS 3.3 was used to create a map of land suitability by preparing a database and inserting the data using GIS for the land suitability analysis of each factor using SIEVE Analysis. This could be done by presenting the factor data on a map, such as creating a map of the industrial density factor which shows the density in 3 shades of color. The darkest color means the distance between each factory is 0-500 meters. The moderate color means the distance between each factory is 501-1,000 meters and the lightest color means the distance between each factory is over 1,000 meters. The resultant map including all 12 factors is shown in Figure 7.

Table 1. Factors and score for the land analysis for development into an eco-industrial town

\begin{tabular}{|c|c|c|c|c|c|}
\hline \multirow{2}{*}{ Factor } & \multirow{2}{*}{$\begin{array}{c}\text { No. of } \\
\text { Sub-Factor }\end{array}$} & \multirow{2}{*}{ Unit } & \multicolumn{3}{|c|}{ Criteria } \\
\hline & & & 3 score & 2 score & 1 score \\
\hline The industry density factor & 1 & Meter & $0-500$ & $501-1,000$ & $>1,001$ \\
\hline The industrial cluster factor ( 9 clusters) & 9 & Meter & $0-500$ & $501-1,000$ & $>1,001$ \\
\hline The accessibility to green and recreation areas factor & 1 & Meter & $0-500$ & $501-1,000$ & $>1,001$ \\
\hline The risk to the urban ecology and environment factor & 1 & Meter & $0-50$ & $51-150$ & $151-500$ \\
\hline
\end{tabular}


Industrial density factor

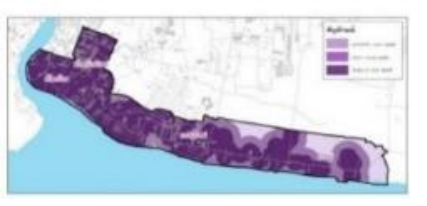

Risk of urban ecology and
environment factor

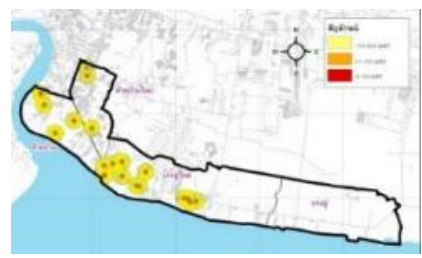

Accessibility to green and recreations area factor

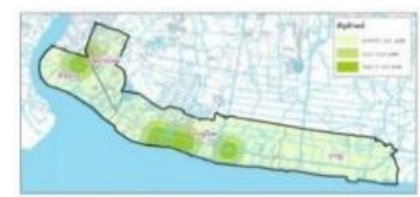

Industrial cluster factor

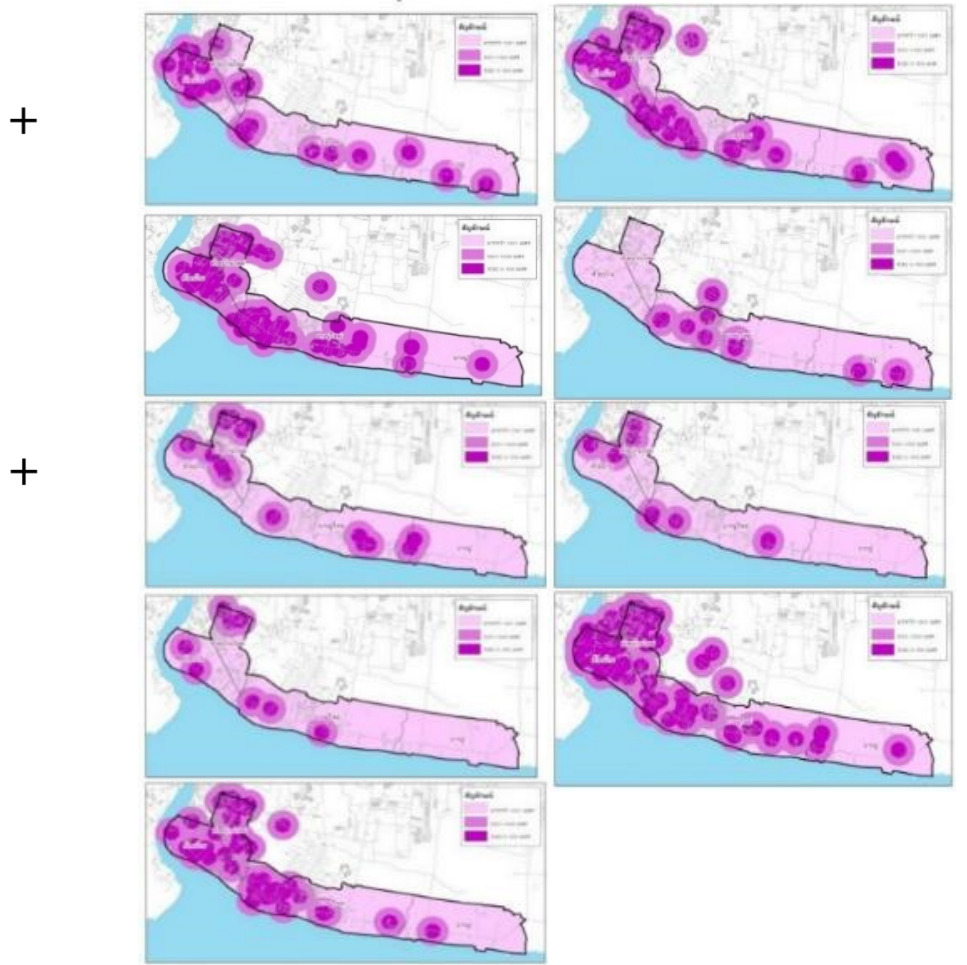

Figure 7. A map of the analysis of land suitability for each factor

After that, the maps are overlaid, which is called (Overlay Analysis) based on Boolean algebra [23]. GIS is used in this technique for analysis, and the concept is shown in Figure 8.

\begin{tabular}{|c|c|c|c|c|c|c|c|c|c|c|}
\hline \multicolumn{3}{|c|}{ Input Theme A } & & \multicolumn{3}{|c|}{ Input Theme B } & & \multicolumn{3}{|c|}{ Output Theme C } \\
\hline $1-13$ & $1-23$ & $1-34$ & & $1-14$ & $1-22$ & $1-32$ & & 7 & 5 & 6 \\
\hline 2-1 0 & $2-21$ & $2-30$ & + & $2-15$ & $2-25$ & $2-35$ & + & 5 & 6 & 5 \\
\hline 3-12 & $3-24$ & 3-3 6 & & $3-14$ & 3-2 1 & 3-31 & & 6 & 5 & 7 \\
\hline \multicolumn{11}{|c|}{ Raster Cell 1-1: 3+4 = 7} \\
\hline \multicolumn{11}{|c|}{ Raster Cell 1-2: $3+2=5$} \\
\hline \multicolumn{11}{|c|}{ Raster Cell 1-3: $4+2=6$} \\
\hline
\end{tabular}

Figure 8. Overlay SIEVE Analysis using addition

Next, the suitability score of all factors is determined. "S" is the Total Suitability Score, "N" is the number of factors and " $R$ " is the weight of the suitability score of each factor from 1 to $\mathrm{n}$ as equation (1)

$$
S=\sum_{i=1}^{n} R_{i}
$$

The area then is divided, this research article divided the area into 4 levels (or 4 intervals):

The most suitable, good suitability, moderate suitability and the least suitable area.

\subsection{Step 4: the offer of Land Suitability with Committees}

This step shows the results for land suitability for development into an eco-industrial town for the working group and committees. The results will be presented in the next section.

\section{Results}

The analysis of 12 factors shows that each one has a chance to get a score $(3,2$ or 1$)$ so this means the maximum score is 36 . After dividing the area into 4 class intervals by referring to Land Suitability Analysis User Guide of the NC Division of Coastal Management and the NC Center for Geographic Information and Analysis [23]. The research separates the scores into equal intervals, which is 9 , as shown in Table 2.

Table 2. The interpretation of the score

\begin{tabular}{|c|c|}
\hline Score & Interpretation \\
\hline $0.00-9.00$ & The least suitable area \\
\hline $9.01-18.00$ & A moderately suitable area \\
\hline $18.01-27.00$ & A good suitable area \\
\hline $27.01-36.00$ & The most suitable area \\
\hline
\end{tabular}

The results of the spatial analysis using GIS to determine land suitability for the development of Samut Prakan into an eco-industrial town are divided into the most, a good, a moderate and the least suitable areas. This analysis defines 5 areas as shown in Figure 9 and includes areas A1, A2, A3, A4 and A5. 


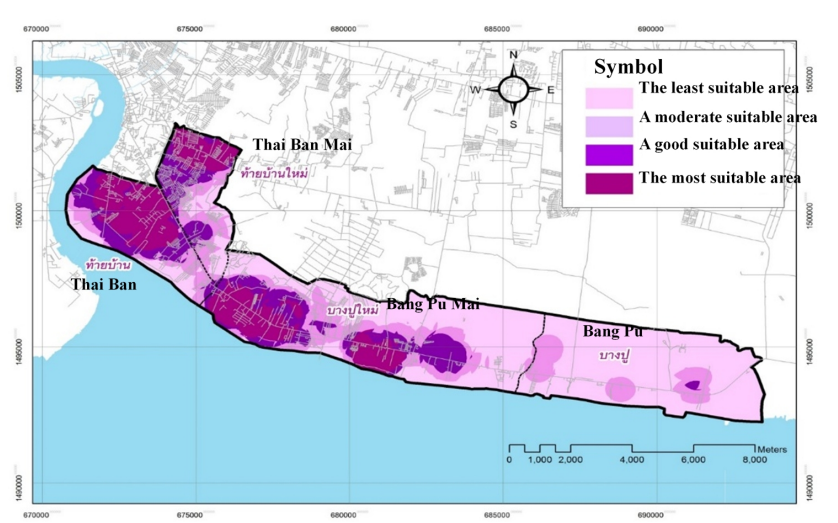

Figure 9. The results of land suitability in Samut Prakan province for development into an eco-industrial town

There are 408 out of 592 factories in the target area, which is equal to $68.92 \%$. Furthermore, the analysis shows that there are 154 factories, which is equal to $26.01 \%$, in area A3 covering the most suitable area with a size of 2.37 square kilometers as shown in Table 3.

Table 3. The details of the suitable area

\begin{tabular}{|c|c|c|c|c|c|c|c|c|c|}
\hline \multirow{2}{*}{ No. } & \multirow{2}{*}{ Area } & \multirow{2}{*}{ Tambon } & \multicolumn{5}{|c|}{ Suitable Area (square kilometers) } & \multicolumn{2}{|c|}{ Factory } \\
\hline & & & the most & a good & a moderate & the least & Total Area & Number & Percentage \\
\hline 1 & A1 & Thai Ban Mai & 1.75 & 0.31 & 0.11 & - & 2.17 & 62 & 10.47 \\
\hline 2 & A2 & Thai Ban & 1.95 & 1.55 & 0.69 & 0.45 & 4.64 & 51 & 8.61 \\
\hline 3 & A3 & Thai Ban & 2.37 & 0.7 & 0.01 & - & 3.08 & 154 & 26.01 \\
\hline 4 & A4 & $\begin{array}{l}\text { Thai Ban \& } \\
\text { Bang Pu Mai }\end{array}$ & 1.98 & 0.51 & 0.45 & 0.33 & 3.27 & 115 & 19.43 \\
\hline 5 & A5 & Bang Pu Mai & 1.19 & 0.32 & 0.22 & 0.19 & 1.92 & 26 & 4.39 \\
\hline \multicolumn{3}{|c|}{ Total } & 9.24 & 3.39 & 1.48 & 0.98 & 15.08 & 408 & 68.92 \\
\hline \multicolumn{3}{|c|}{ Percentage } & 61.26 & 22.46 & 9.8 & 6.48 & 100 & & \\
\hline
\end{tabular}

\section{Conclusions}

This research article presents the land suitability evaluation for the development of a target area in the municipality of Bang Pu, which is located in Samut Prakan, Thailand into an eco-industrial town. There are 4 main factors used for the analysis, including the industrial density factor, the industrial cluster factor, the accessibility to green and recreation area factor and the risk to the urban ecology and environment factor. After applying the information of 5 target areas (A1-A5) into the GIS model, there are 408 industrial factories, which is equal to $68.92 \%$, of 592 Type 3 industrial factories that are suitable locations to be developed into an eco-industrial town. However, the committee voted that area A3, which covers Tambon Thai Ban with an area of 2.37 square kilometers, will be developed into an eco-industrial town because of the limitation of the allocated budget. There are 154 industrial factories in the A3 area, which is equal to $26.01 \%$. The result is important information for the Provincial Governor's Office to consider with regard to land suitability, strategic planning, master plan planning and effective resource allocation to develop the province into an eco-industrial town, which is in line with the vision of the province; moreover, this can be a prototype for other areas.

\section{Acknowledgements}

The researcher would like to thank the Provincial Governor's Office, Samut Prakan Provincial Industry Office, the Federation of Samut Prakan, the Chamber of Commerce of Samut Prakan, Sripatum University, Kasetsart University Sriracha campus and every stakeholder for the advice, data support and resources that helped the researcher achieve this research as purposed.

\section{REFERENCES}

[1] Panyathanakun V, Tantayanon S, Tingsabhat C, Charmondusit K. Development of eco-industrial estates in Thailand: initiatives in the northern region community-based eco-industrial estate. Journal of Cleaner Production 2013; 51: $71-9$.

[2] Audra J PC. Choctaw eco-industrial park: an ecological approach to industrial land-use planning and design. Landscape and Urban Planning 1998; 42: 239-57.

[3] Liwarska-Bizukojc E, Bizukojc M, Marcinkowski A, Doniec A. The conceptual model of an eco-industrial park based upon ecological relationships. Journal of Cleaner Production 2009; 17: 732-41.

[4] Lowe E, Evans LK. Industrial ecology and industrial ecosystems. Journal of Cleaner Production 1995; 3: 47-53.

[5] Chertow MR. "Uncovering" industrial symbiosis. Journal of Industrial Ecology 2007; 11: 11-30.

[6] Department of Industrial Works. Eco-industrial town Development Manual Volume 1; 2012.

[7] Lowe E. Creating by-product resource exchanges: strategies for eco-industrial parks. Journal of Cleaner Production 1997; 5: 57-66.

[8] Chiu ASF, Yong G. On the industrial ecology potential in Asian developing countries. Journal of Cleaner Production 2004; 12: 8-10.

[9] Roberts BH. The application of industrial ecology principles and planning guidelines for the development of eco-industrial parks: an Australian case study. Journal of Cleaner Production 2004; 12: 997-1010.

[10] Park HS, Rene ER, Choi SM, Chiu ASF. (2008). Strategies for sustainable development of industrial park in Ulsan, South Korea-from spontaneous evolution to systematic expansion of industrial symbiosis. Journal of Environmental Management 2008; 87: 1-13.

[11] Zhang L, Yuan Z, Bi J, Zhang B, Liu B. Eco-industrial parks: national pilot practices in China. Journal of Cleaner Production 2010; 18: 504-10.

[12] Marjan J, Hanieh S, Mostafa M. Application of sustainable urban development in environmental suitability analysis of education land use by using AHP and GIS in Tehran. Procedia 
Engineering 2011; 21: 72-80.

[13] Boons F, Spekkink W, Mouzakitis Y. The dynamics of industrial symbiosis: a proposal for a conceptual framework based upon a comprehensive literature review. Journal of Cleaner Production 2011; 19: 905-11.

[14] Jung S, Dodbiba G, Chae SH, Fujita T. A novel approach for evaluating the performance of eco-industrial park pilot projects. Journal of Cleaner Production 2013; 39: 50-9.

[15] Ketsarapong, S. Master Plan for Research Project "Eco-industrial town project in Samut Prakan Province". Faculty of Engineering, Sripatum University. 2015.

[16] Ruckelshaus W. Toward a sustainable world. Scientific American 1989; 262: 166-70.

[17] Industrial Estate Authority of Thailand (IEAT). Eco-industrial town: The Beginning of an Eco-industrial town Manual. 2009.

[18] Xiangsheng D, Shasha L, Jing W. Ecological strategy of city sustainable development. APCBEE Procedia 2013; 5: 429-34.
[19] Liu H, Zhou G, Wennersten R, Frostell B. Analysis of sustainable urban development approaches in China. Habitat International 2014; 41: 24-32.

[20] Ketsarapong, S. Final Report for Research Project "Eco-industrial town project in Samut Prakan Province". Faculty of Engineering, Sripatum University. 2015.

[21] Bunruamkaew K. Murayama Y. Site suitability evaluation for ecotourism using GIS \& AHP: a case study of Surat Thani Province, Thailand. Procedia-Social and Behavioral Sciences, 2011; 21: 269-78.

[22] Mohurd. The national standards for developing national garden city (in Chinese). [cited 2016 Apr 9]. Available from http://www.mohurd.gov.cn/zcfg/jsbwj_0/jsbwjcsjs/200611/ t20061101_156922.html

[23] NC Division of Coastal Management \& NC Center for Geographic Information and Analysis. (2005). Land Suitability Analysis. User Guide. For ArcView 3.x and ArcGIS 9.x. [cited 2016 Apr 9]. Available from http://portal.ncdenr.org 